Article

\title{
Food Festivals and the Development of Sustainable Destinations. The Case of the Cheese Fair in Trujillo (Spain)
}

\author{
José Antonio Folgado-Fernández ${ }^{1, *(\mathbb{D})}$, Elide Di-Clemente ${ }^{2} \mathbb{C}$ and \\ José Manuel Hernández-Mogollón ${ }^{2}$ (D) \\ 1 Department of Financial Economics and Accounting, University of Extremadura, 10071 Cáceres, Spain \\ 2 Department of Business Management and Sociology, University of Extremadura, 10071 Cáceres, Spain; \\ ediclemente@unex.es (E.D.-C.); jmherdez@unex.es (J.M.H.-M.) \\ * Correspondence: jafolgado@unex.es
}

Received: 26 April 2019; Accepted: 19 May 2019; Published: 23 May 2019

\begin{abstract}
Food-based events and festivals are being increasingly organized around the world, both in large cities and in small towns with the aim of attracting the many benefits they provide to the destinations where they are held. While the impact of mega events is sufficiently studied in scientific literature, the works that address the effects of small events are still scarce. To close this gap, this research investigates the significance of small food-based events for tourism and the sustainable development of destinations. An exhaustive study of a renowned festival based on cheese was carried out in the Spanish city of Trujillo. A survey was used to ask non-local attendants and it explored their motivations, the event itself, the assessment of the permanent elements of the destination, and loyalty to the festival. The impact of these small festivals is not only relevant for the tourism sector and the sustainable positioning of the destination, however it is also relevant for the local economy due to the consumption of local gastronomic products. Given their role in attracting visitors, these small festivals as tourist motivators must be integrated into the communication campaigns of those destinations that seek to enhance their sustainability.
\end{abstract}

Keywords: cheese festival; local food; small event; tourism management; sustainable destination

\section{Introduction}

The promotion of various quality local foods such as wine, fruits and vegetables, fish and meat, or cheeses can be an important reason to organize festivals and events in the territory where they are obtained or produced as they can provide benefits both for tourists and for the local population, usually located in rural enclaves [1]. These gastronomic festivals have a limited duration, they are usually held once a year, and they offer tasting and purchase of products linked to the territory where the festival is held. In addition to projecting a positive image which attracts tourism, they create an awareness in the residents of the region or territory where the production is done, while promoting the sustainable local economy and contributing to the development of the area [2].

Consequently, the gastronomic events of local products linked to the destination represent an important source of income for rural areas and at the same time can help to create an image of a sustainable destination. These revenues are mainly produced during the festival with the purchase of products at the destination, however they can be developed with subsequent commercialization once the tourist has returned to the place where they live.

Gastronomic festivals are considered to be an opportunity to promote authentic local products, so it can be a good opportunity to promote rural areas at risk of depopulation, as well as connect 
various European regions around a single characteristic product by creating gastronomic festivals with links and premises based on the sustainable development of the destination. This sustainable development can be fostered from the union between sustainable territory and gastronomic festivals based on authentic products of recognized quality. This tourism offers the option of preserving the culture and uniqueness of a territory based on its food, the creation and safeguarding of jobs that promote the economic development of the area, and contribute to being environmentally conscious as they are small cottage industries with reduced emissions [3].

The tradition of gastronomic festivals is very long and this type of tourism is currently recognized as one of the future trends of tourism development, especially for those events that are based on indigenous and handcrafted quality products in the context of sustainable destinations. These events often become a tourism resource in itself, bringing the tourist closer to the product through its consumption or tasting and favoring the local economy by creating jobs around a food product that is unique and of quality [4].

The objective of this study is to investigate the attitudes and motivations of tourists of gastronomic events linked to the sustainable development of the destination where they are developed. In this case, it is an analysis of the gastronomic tourists visiting Trujillo in the Spanish region of Extremadura, which is a recognized cultural and nature destination. This territory stands out for its conservation and for the production of products of recognized quality with an attachment and respect for the territory. The secondary objectives of the study is to identify the role that gastronomic tourism initiatives can play as a strategic tool to achieve conservation, and protection of the sustainability of the territory. To achieve this purpose, the following section reviews significant literature on the subject and presents the hypotheses included in the structural equations model, and this is to be empirically tested using the data from one gastronomic festival. Subsequent sections are devoted to discuss the results and present the conclusions.

\section{Theoretical Framework and Hypothesis Development}

\subsection{Local Gastronomy and Sustainable Destinations}

The needs of tourists are changing and tourists are increasingly concerned about the sustainability of the destination they visit thanks to growing environmental awareness [3]. Local gastronomy can contribute to the sustainability of the territory since it not only covers areas such as agricultural and livestock production, however it is also important in other areas such as education, nature conservation, tourism, or urban planning [5] In this sense, in a world where the importance of place is increasingly emphasized, local food is emerging as a place-making tool [6]. Thus, tourists increasingly give more importance to the food they consume on their trips, especially if it is local quality products with links to identity and culture [7].

Tourism that has gastronomy as the central axis is compatible with other types of tourism in the territory, such as cultural, rural, or heritage. Gastronomic tourists value the authenticity and the traditions of the rural and agricultural world where the processes of food and drink elaboration take on great educational protagonism $[8,9]$.

These local foods with a tradition of quality can provide differential development for the gastronomic identity of the territory which cultivates the attraction of a new gastronomic tourist concerned about the quality of the food they consume and the sustainability of the territory where it is produced [7]. In this way, tourists can get to know the culture of a territory through gastronomy, being able to visit food-based museums and thematic interpretation centers, learn how to prepare typical dishes of the area, or attend traditional events, festivals, or livestock centers $[10,11]$.

Emerging in all of these tourism activities is the need to value the sustainability component of gastronomic tourism since on many occasions the food is produced from traditional agricultural or livestock activity that has meanwhile managed to maintain the artisan techniques, preserving the environment and providing a differential quality of the product [3]. The sustainability component 
of gastronomic tourism may be used as a tool to add value to local produce and enhance the local identity of both the destination and its local community [9]. Thus, the consequence of an agricultural or livestock activity committed to respecting the destination and its sustainability is that it can be complemented with gastronomic tourism and become a tool for sustainable local development [12]. In this way, gastronomic tourism based on local products maintains links with the destination where they are produced and their local community. It is an opportunity to preserve the sustainability of the territory, to promote the local culture based on unique foods with an identity, and to promote the economic development of the destination [13].

The local gastronomic products obtained in a traditional way and one that is respectful of the environment represent a great opportunity to improve sustainability in the territory and strengthen the local economy. This positioning can attract tourism based on quality artisan food and the authenticity of the destination [7].

\subsection{Gastronomic Tourism and Food Festivals}

Gastronomy in all its expressions influences the feeling of identification with the territory and the involvement of both tourists and residents [13]. Local gastronomy and craftsmanship can be related to cultural routes, markets, events, or festivals using the local gastronomic heritage as a tourism attraction and as integrated territorial development of its inhabitants [14].

For its part, the current context of globalization makes it difficult for small rural agribusinesses to reach the minimum productivity levels to compete in international markets. Many of these small industries could progress in their business, complementing their main activity with others related to tourism. For example, with the sale and tasting of authentic gastronomic products or offering tourism services and activities linked to food in order to meet the demands of a new tourist interested in discovering the production environment and with the aim of learning about the product culture in the territory itself [15].

Gastronomic festivals based on regional products are a growing phenomenon in development. Both large cities and small towns can express their unique and distinctive character by means of their local handcrafted quality products that can become a key factor for tourist satisfaction and for the image of the destination where they are carried out [16,17].

These events can be an alternative opportunity for tourism as they provide economic development for the regions and value local products both for the economic impact of their purchase [18] as well as for the image that these foods bring to the region where they are produced [17]. This last aspect is of vital importance since the positive impressions of the gastronomic festivals can be transferred to the whole host tourist territory which can influence the promotion of future visits and the purchase of gastronomic products in the places where the tourists live or work once they finish their trip [19]. These fairs can also influence the creation of an awareness associated with the sustainable destiny of production through brands that were unknown and that contribute to differentiation of the destination [17].

Noteworthy of these tourist activities are those that revolve around local products and foods of recognized quality, along with the promotion of fairs and festivals associated with each product [7]. In this sense, more and more innovative products are emerging, such as the European gastronomic routes that are developed in areas with an important agricultural production of certified quality (mainly in Spain, France, and Italy), such as the recognized European routes of cheese, wine, ham, or olive oil [20].

One of the incipient typologies of gastronomic tourism is tourism for cheese, which entails the visit to zones of milk and cheese production, cheese festivals, restaurants, or specialized establishments, with the purpose of tasting, knowing, making, or learning about this product [21].

\subsection{Gastronomic Events and Tourist Loyalty: Theoretical Model}

The loyalty of the tourist can contribute additional economic value to the destination since it implies sustained revenues over time, as well as being more profitable to retain a tourist than to 
capture a new one [22]. This relationship of tourist satisfaction with the destination with loyalty is widely recognized in the bibliography of a multitude of scientific works. Most of them pose a direct relationship between tourist satisfaction and their intention to recommend or enjoy it again, thus becoming an indicator of loyalty as a continuation of the experiences enjoyed in the place [23-26].

In this way, the gastronomy of the territory as a whole or the celebration of thematic festivals of some product with territorial identity can transmit an improvement of the overall satisfaction of the tourist and become the most memorable part of the trip. This situation also provides the possibility of transmitting a new image of both the territory and the festival by the tourist on their return. Recommendations are made based on artisanal and respectful gastronomic experiences, reinforcing the values of competitiveness and sustainability of the territory [24].

The consumption and tasting of the food of a location contributes to the tourist being more likely to be satisfied with the experience at the destination, especially through the celebration of gastronomic festivals. These events contribute to the tourist's return and recommendation to their friends and family of the experience that they have enjoyed [23]. It should also be taken into account that the effectiveness of holding these events based on indigenous products in terms of generating positive impacts on the overall satisfaction of the tourist experience depends to some extent on the size and popularity of the event, the organization, or the active participation of tourists [24].

In this context, the attractions of the destination together with those of a gastronomic event based on quality local products can complete a global satisfaction of the tourist that favors recommending the festival and/or returning for the next edition $[25,26]$. The explanation for tourist loyalty can be found in the offer of unique products and experiences which in many cases can only be enjoyed in the production destination itself and on limited dates of the season based on authenticity, typicality, and the flavor of the food [17].

In this way, our main intention is to verify if the attractions of the destination and those of a gastronomic festival (based on sustainable products of recognized quality of the territory where it is celebrated) influence, and to what extent, the overall satisfaction of the tourist in the sustainable destination and in their intention to return and/or recommend the gastronomic festival.

Based on the previous research proposals, the different hypotheses of the investigation are presented:

H1. There is a positive relationship between the attractions of the destination and the overall satisfaction of the tourist.

H2. There is a positive relationship between the attractions of a gastronomic festival and the overall satisfaction of the tourist.

H3. There is a positive relationship between the attractions of the destination and the loyalty of the tourist to the gastronomic festival.

H4. There is a positive relationship between the attractions of a gastronomic festival and the loyalty of the tourist to the gastronomic festival.

H5. There is a positive relationship between the overall satisfaction of the tourist and his loyalty to the gastronomic festival.

All of this is specified in the following hypotheses which can be observed in Figure 1. 


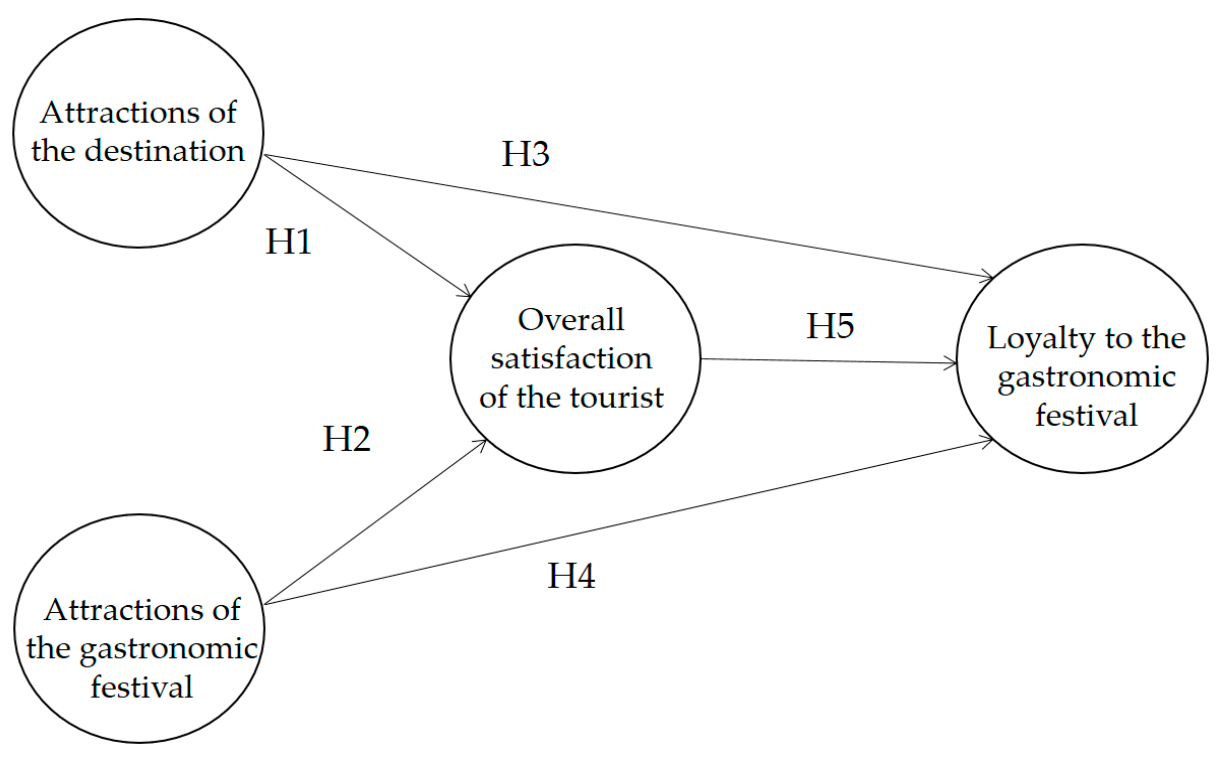

Figure 1. Proposed model.

\section{Materials and Methods}

\subsection{Research Scenario}

The research is conducted in the Spanish city of Trujillo, located in southeastern Europe in the Spanish province of Cáceres (Extremadura). Trujillo has a population of around 10,000 inhabitants. The historical relevance has made this city an important tourist center, famous for its monuments, its medieval city, its natural environment, and its native cuisine where its cheeses stand out. It was the city of birth of Francisco Pizarro, conqueror of Peru, whose equestrian sculpture, which is an icon that is representative of this city, rises in its Plaza Mayor. It is here where the National Cheese Fair is celebrated every year. This event is considered one of the most important international cheese dates for the whole sector for the promotion, tasting, and purchase of the best national and international artisan cheeses. The region of Extremadura is considered as a whole as a sustainable destination with high quality indigenous foods. It is also a reference in terms of nature and cultural tourism.

\subsection{Method of Obtaining Data and Scales of Measurement}

The information was collected through a personal survey of each tourist through a structured questionnaire during their gastronomic experience. The choice of this technique as a method of data collection is justified by the interest in reaching a sample as large as possible since the study population is the tourists who visit the Trujillo National Cheese Fair.

The objective is to collect useful information in order to analyze to what extent the characteristics of sustainable destinations and gastronomic events adapt to the attitudes and motivations of the tourists who participate in them. In this sense, the most general characteristics that could be valued by all tourists were selected, both for those with and without previous experience in the location.

In order to elaborate the questionnaire that fulfilled our objective, several revisions were carried out with the purpose of perfecting it and corroborating its validity [27]. It was submitted to the pre-test of a small group of individuals who were requested to analyze the questionnaire to indicate aspects to be improved [28].

The questionnaire was divided into two sections. The first block dealt with sociodemographic questions that help with the segmentation of the population, such as the place of origin, gender, age, or training in progress. Next, questions were raised about the motivations to go to the destination and its attractions. Next, issues related to the sustainable destination and the gastronomic event that takes place were addressed. The last block gathered questions about the general perception that tourists have 
about their overall satisfaction and their availability to enjoy it again or recommend it. The variables were measured on a Likert scale of 5 points $(1=$ strongly disagree, $5=$ strongly agree).

Sampling was carried out through a convenience procedure, conducting interviews based on a population of tourist consumers over the age of 18. A total of 323 responses were obtained, however 11 questionnaires had to be discarded since they lacked more than $15 \%$ of the information. Therefore, there was a final sample of 312 responses from people who attended the National Cheese Fair during 1-5 May 2013.

On the other hand, adapted scales, already used in previous studies, were used to measure the different constructs of the theoretical model. The attractions of the destination were valued on scales based on culture, heritage, history, entertainment $[29,30]$, the sensitivity and environmental responsibility of the destination [31], and the quality of life in the sustainable destination [32]. For the evaluation of the attractions of the festival, adapted scales were used based on their notoriety, recognition and impact, identity with the local community, or the degree of participation of the residents in it $[30,33]$. Meanwhile, overall satisfaction at the destination was evaluated using adapted scales $[34,35]$ on the overall perception of the tourist during their stay.

Finally, to analyze the loyalty of the gastronomic tourist to these types of events based on the quality of local products, scales were adapted to measure the intention of the tourists in terms of returning and/or recommending the gastronomic festival that they were attending [23].

\subsection{Data Analysis}

With the data obtained, a descriptive analysis was carried out using the SPSS v23 program (IBM, New York, NY, USA). The theoretical model was evaluated using the partial least squares (PLS) path modeling technique with Smart 3.2.7 (PLS, Bönningstedt, Germany) to validate the hypotheses. Based on the present study's objectives and use of some formative indicators, the PLS-path method appeared to be the most suitable for this study [36].

\section{Results}

This section deals with the evaluation of the data obtained and the discussion of the results. In this way, the descriptive analysis is presented in the first part, then the evaluation of the measurement model (specifying the relationships between the indicators and the constructs) and the structural model (evaluating the existence and magnitude of the relationships between latent variables), ending with the consequent assessment of the hypotheses raised.

\subsection{Descriptive Analysis}

The 312 valid questionnaires were evaluated based on the sample of tourist consumers over 18 years of age. This characterization of tourists is especially relevant because it could be correlated with their level of attachment to local foods in destinations with sustainable characteristics [37]. The sample is made up of a slightly higher proportion of women (170 women per 142 men) and practically one in two were between 40 and 59 years old. Regarding the level of training, half of the respondents had completed higher education (49.51\%), $23.86 \%$ had a bachelor's degree or professional training, and $25.49 \%$ had completed other studies.

On the other hand, in the analysis carried out on the region of origin of the tourists surveyed, the region of Madrid stands out (51.8\%), even above Extremadura (22.4\%), which is the community developing the events. The rest of the Spanish regions account for $25 \%$. Regarding the percentage of foreign tourists, the indication is that it is not statistically significant as they were only $1 \%$ of respondents.

The age group between 40 and 59 years of age is the largest (49.36\%) while the youngest tourists (18-25) represent the smallest category with only $12 \%$ of respondents (see Table 1). 
Table 1. Characterisation of respondents.

\begin{tabular}{cccc}
\hline & Responses & Number of Responses & $\%$ \\
\hline \multirow{2}{*}{ Gender } & Man & 142 & 45.51 \\
& Women & 170 & 54.49 \\
\hline \multirow{2}{*}{ Age } & $<25$ & 37 & 11.86 \\
& $26-39$ & 75 & 24.04 \\
& $40-59$ & 154 & 49.36 \\
& $60+$ & 46 & 14.74 \\
\hline \multirow{2}{*}{ Origin } & Capital of the country (Madrid) & 160 & 51.2 \\
& Resident of region (Extremadura) & 69 & 22.1 \\
& Other region & 78 & 25 \\
& Other country & 5 & 1.6 \\
\hline
\end{tabular}

As for the motivations of the trip (analyzing the value of the means $\bar{X}$ ), the main motivation was to travel with family and friends $(\bar{X}=4.37)$. The second motivation was to attend the gastronomic festival $(\bar{X}=4.35)$, followed by enjoying the gastronomy $(\bar{X}=4.24)$, getting to know the cultural heritage $(\bar{X}=3.88)$, and rest and relax $(\bar{X}=3.79)$. The lowest value was for the item to visit friends and relatives $(\bar{X}=2.45)$. Table 2 shows the mean and standard deviation for the different motivations which indicates the difference between a particular value and its average (see Table 2).

Table 2. Motivations.

\begin{tabular}{ccc}
\hline Category & $\overline{\mathbf{X}}$ & $\boldsymbol{\sigma}$ \\
\hline Travel with family and friends & 4.37 & 0.878 \\
Attend the event & 4.35 & 0.722 \\
Enjoy the gastronomy & 4.24 & 0.687 \\
Get to know culture and heritage & 3.88 & 0.692 \\
Rest and relaxation & 3.79 & 0.860 \\
Visit family and friends & 2.45 & 1.180 \\
\hline
\end{tabular}

\subsection{Measurement Model}

The evaluation of the measurement model was carried out by means of the analysis of the validity and reliability of the different constructs, differentiating those that are reflective from the formative ones. The reflective or formative nature of concepts determines the type of analysis to be performed. The constructs' reflective or formative nature was determined based on the guidelines proposed by Hair et al. (2010). Thus, an attempt was made to assess whether the theoretical concepts were measured accurately by means of the observed variables [38].

For reflective constructs (overall destination satisfaction and loyalty to the gastronomic event), the results of the evaluation suggest an adequate individual reliability of the items since all the values are well above the minimum threshold of 0.505 [39]. The analysis also indicates that all values are statistically significant at the $99.99 \%$ level. Regarding the Cronbach's alpha values reached, evidence shows that they are greater than the established minimum threshold of 0.6 and the composite reliability for the two reflective constructs is greater than 0.7 , thus validating the internal consistency of the model [38]. The convergent validity was evaluated from the mean variance extracted by construct (AVE), where all the constructs presented values higher than the recommended minimum of 0.50 [39] (Table 3).

On the other hand, the property of discriminant validity is verified since the correlations between the constructs are smaller than the square root of the average extracted variance, sharing more variance with their indicators than with the other constructs. Table 3 shows that the discriminant validity was further analyzed by the development of the load matrix and cross-loads (loadings and cross-loading), verifying that the indicators carry more weight on their construct than on the rest of the items. 
In addition, each construct carries more force on its indicators than others. In this way, they satisfy the established discriminant validity condition [39]. In addition, discriminant validity can be measured through the Heterotrait-Monotrait ratio (HT-MT). HT-MT ratio must be lower than 0.90 to establish discriminant validity, a condition which was satisfied [40].

Table 3. Individual item reliability and internal consistency indicators.

\begin{tabular}{|c|c|c|c|c|c|}
\hline Reflective Construct & Indicators & Loadings & $\begin{array}{c}\text { Cronbach's } \\
\text { Alpha }\end{array}$ & $\begin{array}{l}\text { Composite } \\
\text { Reliability }\end{array}$ & AVE \\
\hline $\begin{array}{l}\text { Overall satisfaction } \\
\text { of the tourist }(\mathrm{R})\end{array}$ & $\begin{array}{ll}- & \text { Overall image } \\
- & \text { I enjoy visiting this destination } \\
- & \text { I get good deals when I visit } \\
\text { this destination } \\
\text { - } \quad \text { This destination has a good name } \\
\text { and reputation }\end{array}$ & $\begin{array}{l}0.557^{* * *} \\
0.786^{* * *} \\
0.760^{* * *} \\
0.699^{* * *}\end{array}$ & 0.764 & 0.796 & 0.518 \\
\hline $\begin{array}{l}\text { Loyalty to the } \\
\text { gastronomic festival } \\
\text { (R) }\end{array}$ & 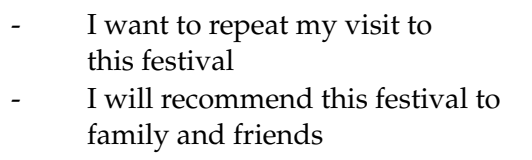 & $\begin{array}{l}0.883^{* * *} \\
0.866^{* * *}\end{array}$ & 0.692 & 0.866 & 0.764 \\
\hline Formative Construct & Indicators & Weights & & & \\
\hline $\begin{array}{l}\text { Attractions of the } \\
\text { destination (F) }\end{array}$ & $\begin{array}{ll}- & \text { Local cuisine } \\
\text { - } & \text { Local culture and traditions } \\
\text { - } & \text { Local stores } \\
\text { - } & \text { Entertainment } \\
\text { - } & \text { Sustainability } \\
\text { - } & \text { Quality of life }\end{array}$ & $\begin{array}{l}0.554^{* * *} \\
0.244^{* *} \\
0.163^{* *} \\
0.267^{* * *} \\
0.256^{* *} \\
0.442^{* * *}\end{array}$ & & & \\
\hline $\begin{array}{l}\text { Attractions of a } \\
\text { gastronomic festival } \\
\text { (F) }\end{array}$ & $\begin{array}{ll}\text { - } & \text { The event is well known at a local } \\
\text { and national scale } \\
\text { - } & \text { Community identity } \\
\text { - } & \text { Organizing } \\
\text { - } & \text { Authentic experience } \\
\text { - } & \text { When I am thinking about } \\
\text { gastronomic festivals, this event } \\
\text { comes to mind immediately } \\
\text { - This event is turning out better } \\
\text { than I expected }\end{array}$ & $\begin{array}{l}0.369^{* * *} \\
0.114^{*} \\
0.204^{* *} \\
0.251^{* *} \\
0.445^{* * *} \\
0.370^{* *}\end{array}$ & & & \\
\hline
\end{tabular}

Abbreviations: F, formative indicator; $\mathrm{R}$, reflective indicator. Notes: Critical $t$-values: ${ }^{*} p<0.05$; ${ }^{* *} p<0.01$; ${ }_{* * *} p<0.001$; (based on $t(4999)$, one-tailed test); $t(0.05 ; 4999)=1.645 ; t(0.01 ; 4999)=2.327 ; t(0.001 ; 4999)=3.092$.

Regarding the evaluation of the formative constructs (attractions of the destination and attractions of the gastronomic event), the analysis of multicollinearity was carried out. The results obtained from the VIF ranged from 1.033 to a maximum of 1.517, figures below the restrictive threshold of 3.3 [41] and even lower than the commonly accepted value of 5 [38]. The evaluation of the value of the weights revealed that all values are above 0.1 [42]. A bootstrapping technique with 5000 samples was used to analyze the statistical significance and stability of the estimates. From the application of this bootstrapping process, the results verified the significance of the totality of the indicators ( $t=1.964726835$ for $95 \%$ confidence, $t=2.585711627$ for $99 \%$, and $t=3.310124157$ for $99.99 \%$ ) [38] (Table 3). In this way, the results achieved confirm that the measurement model has the necessary reliability and validity so that the structural model could be evaluated below.

\subsection{Structural Model}

After analyzing the measurement model, the recommended procedures were carried out to evaluate the structural model. Our study is based on the analysis of the values of variance explained and the significance of the paths $[43,44]$. The value of the explained variance of the endogenous constructs (R2) was used for the latent dependent variables in order to analyze the predictive power of 
the model. Thus, it transpires that the proposed model explains $33.3 \%$ of the overall satisfaction of the tourist and $40.5 \%$ of the loyalty to the gastronomic festival (Table 4), indicating that the model has a high predictive value and is able to explain endogenous constructs [45]. However, the values of the coefficients $\beta$ that relate to the constructs of the model reach figures greater than 0.2 [45] or have a value of statistical $t$ greater than 1.96 , so there is the absence of non-significant paths (Table 4).

Table 4. Hypothesis support.

\begin{tabular}{|c|c|c|c|c|}
\hline Hypothesis & $\begin{array}{c}\text { Path Coefficient } \\
(\beta)\end{array}$ & $\begin{array}{c}t \text {-Value } \\
\text { (Bootstrap) }\end{array}$ & Correlations & Support \\
\hline $\begin{array}{l}\text { H1. Attractions of the destination }>>\text { Overall } \\
\text { satisfaction of the tourist }\end{array}$ & 0.129 * & 1.958 & 0.342 & Yes \\
\hline $\begin{array}{l}\text { H2. Attractions of a gastronomic festival >> } \\
\text { Overall satisfaction of the tourist }\end{array}$ & $0.515^{* * *}$ & 8.495 & 0.568 & Yes \\
\hline $\begin{array}{l}\text { H3. Attractions of the destination }>>\text { Loyalty to } \\
\text { the gastronomic festival }\end{array}$ & $-0.010^{\mathrm{ns}}$ & 0.184 & 0.269 & No \\
\hline $\begin{array}{l}\text { H4. Attractions of a gastronomic festival >> } \\
\text { Loyalty to the gastronomic festival }\end{array}$ & $0.503^{* * *}$ & 8.149 & 0.618 & Yes \\
\hline $\begin{array}{l}\text { H5. Overall satisfaction of the tourist }>>\text { Loyalty } \\
\text { to the gastronomic festival }\end{array}$ & $0.210^{* * *}$ & 3.257 & 0.492 & Yes \\
\hline
\end{tabular}

The results of the evaluation of the proposed model are in line with the findings of other previous studies. As for the relationship between the attractions of the destination and the overall satisfaction of the tourist (H1), they agree with the studies of San Martín \& Rodríguez Del Bosque [35]. Consequently, the positive impact of this relationship suggests the importance for the overall satisfaction of the tourist of the permanent attractions of a destination that hosts a gastronomic festival. Regarding the relationship between the attractions of the festival and the overall satisfaction of the tourist $(\mathrm{H} 2)$, the results achieved are in line with those of Sims [11], confirming the important role played by the attractions of a gastronomic festival on the tourist's global satisfaction. According to these authors, this is not a surprising result because the more attractive the authenticity of the festival, the greater the satisfaction of the tourist.

At the same time, the relationship between the attractions of the destination and the loyalty to the festival (H3) could not be proven, which is a consequence of the mediation effect from the overall satisfaction. This result is in line with the results of Folgado-Fernández [25], possibly motivated by the strong impact of festival attractions as the main motivation for the gastronomic tourist.

Regarding the influence that the attractions of the gastronomic festival have on the loyalty of the tourist to the festival (H4), the results agree with those of Wan et al. [26] for tourist loyalty. Therefore, gastronomic festivals based on an endogenous product, in this case, the cheese, present great benefits. Not only is the tourist's stay relevant, however the possibility of them returning to the destination or recommending the experience is also significant. Finally, the results obtained for the relationship of overall satisfaction on the loyalty of tourists to the festival (H5) confirm the general consensus in the literature $[7,18,35]$ about the need to have both elements and permanent attractions of the destination along with those of a festival based on authentic products and the quality of the territory.

The main results of this model reveal that the attractions of the gastronomic event and the overall satisfaction of the tourist are significant predictors of tourist loyalty $(40.5 \%)$, with the most important factor being the attractions of the gastronomic event, followed by the overall satisfaction of the tourist. Equally, both the attractions of the destination and the gastronomic festival (especially these) are predictive factors for tourist satisfaction (33.3\%). In this sense, the majority of the studies $[7,11,14,18]$ have shown that the experiences had during a festival of local food provide a greater perception of 
overall satisfaction to the tourist and contribute to their loyalty to it through revisiting and/or their recommendation (Figure 2).

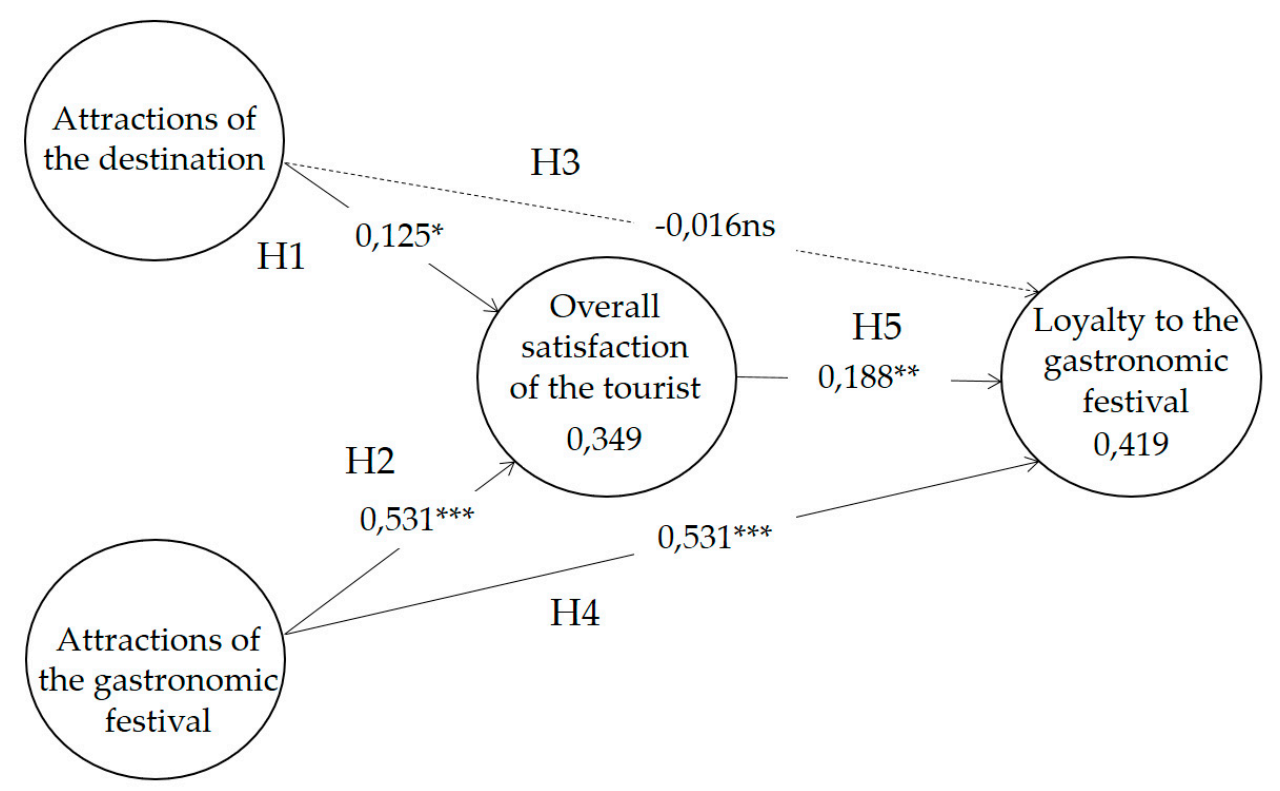

Figure 2. Final structural model.

As a summary, and in light of the results obtained, it can be said that both the attractions of the destination and the gastronomic events have a positive influence on the overall satisfaction of the tourist, although the attractions of the gastronomic festival are greater. On the other hand, the influence of the attractions of the destination on loyalty to the gastronomic event is not significant, while the attractions of the gastronomic event influence loyalty towards it. Finally, it is noted that the overall satisfaction of tourists (formed by the attractions of both the destination and the festival) positively influences the loyalty to festivals based on the quality of local foods, celebrated in the sustainable territories where they are produced.

The results achieved highlight the relevance of the variables analyzed as key elements when considering the strategies and future plans of the tourism managers. You can carry out campaigns to promote gastronomic tourism and food festivals based on the authenticity of the unique and quality food produced in the territory. The values obtained so far serve as a basis for carrying out the appropriate reflections, limitations, and conclusions in the following section.

\section{Discussion}

For the gastronomic tourist, the consumption of food implies, in addition to enjoying the food, having an experience with the products which they identify with the location. Organizing festivals of different contents linked to local products of sustainable territories can represent an opportunity for tourists to enjoy unique experiences while generating the economic development of the area. The positioning of these events contributes to the development of the sustainable destination where they are held and implies the need to have a unique gastronomic product of recognized quality. Additionally, it must have the design of an adequate communication strategy so that it is recognized by tourists ahead of other events and competing destinations.

As the analysis reveals, the attractions of a destination have a positive influence on tourist satisfaction during their experience in a recognized local food gastronomy festival, although they are not significant when it comes to returning or recommending the said festival. For its part, the attractions of the food festival influence-and more clearly than those of the destination-both the general satisfaction of the tourist and their loyalty to the event. At the same time, that general 
satisfaction formed by both the attractions of the destination and the attractions of the event positively contribute to the repetition and recommendation of the festival and the product on which it is based.

The explanation for this situation may be that for the gastronomic tourist, the main motivation they find to travel is the food that they will enjoy at the destination, especially if these are authentic local foods of recognized prestige that are produced in the sustainable territory where the event takes place. All this despite being in a city like Trujillo (Spain), which is recognized for its historical legacy and its great cultural heritage.

In this way, this work provides different implications for both theory and practice. Regarding the former, the study proposes a new conceptual framework that evaluates little explored relationships between different constructs, such as the attractions of the destination, the attractions of the celebration of a gastronomic festival, and the assessment of global tourist satisfaction and tourist loyalty, with the double position of reviewing or recommending it. All this is then coupled with the context of sustainable destinations and authentic gastronomic products of proven and recognized quality that are produced there.

In view of the results obtained, the main practical implications of the study suggest the need to create a clear and coherent marketing strategy between the sustainable destination and gastronomic festivals, basing communication mainly on the value provided by quality products obtained in their own territory. This situation indicates the need for a new orientation in the communication of gastronomic festivals, opting for the binomial sustainable destination and festivals based on gastronomic products of recognized quality obtained in the territory itself which takes into account the connection with culture, history, and the identity of the location.

In this sense, consuming in situ the native product means contributing to the increase of the future sales of the product in the places of residence of the tourists and to generating memories of a complete sensory experience. Likewise, a better coordination of the calendar of events (mainly those of a gastronomic nature) would help to avoid rivalry between coinciding regional festivals as well as being able to plan the arrival of tourists which would mitigate the effect of seasonality on the different sustainable destinations. An additional positive impact could be the increase of the average stay in the destination, adding to the attractions of the place and the participation of the tourist in a unique experience based on gastronomic products. It would also be interesting to connect the intangible attractions of the destination, such as the recipes and local culinary traditions, with the festival's own activities. In this way, tourists could be shown, during the event, the uniqueness and authenticity of a unique and differentiated gastronomic experience. This experience could be based on the most singular tradition as well as on new creative recipes that can be learned by tourists during their visit to the destination.

As for the loyalty of the tourist, the current digital context has multiplied the channels to transmit information in the moment and to the whole world. Gastronomy in general and culinary festivals in particular generate many conversations and images which can be an opportunity to recommend both the festival, the product on which it is based, or the sustainable destination where it is produced. One last relevant contribution, once the results of the study are known, is to encourage creativity and entrepreneurship of small entrepreneurs and local artisans with access to funding from different administrations. In this way, they will maintain and create jobs in rural areas which will generate wealth in their own territory through a food that is produced there.

The main limitation of this analysis is that the study focused on a part of the tourism sector, such as gastronomic events, in a territory (Extremadura, Spain) with very clear values in terms of sustainability. Thus, the results obtained should be interpreted in this context of the investigation and only generalized with due prudence. For its part, future research can focus on replicating, with the necessary adjustments, this research in other destinations and festivals of similar characteristics and with a similar environment. This could confirm these results and explain the ability of gastronomic events to influence the destination's global tourist experience and their loyalty to these types of festivals. 
In short and given that indigenous quality food is an important component of the experience in sustainable destination, the organization of gastronomic festivals can provide a unique differential value that contributes to the development of the territory and its sustainability through the promotion of Authentic products of recognized quality.

Author Contributions: Conceptualization J.A.F.-F. and E.D.-C.; methodology J.M.H.-M. and J.A.F.-F.; validation, J.A.F.-F. and E.D.-C.; writing-original draft preparation, J.A.F.-F. and E.D.-C.; writing-review and editing, J.M.H.-M. and J.A.F.-F.; supervision, J.M.H.-M. and E.D.-C.

Funding: The dissemination of this research has the support of the European Regional Development Fund of the European Union, granted within the framework of the programme "Support for the Implementation of Research Activities and Technological Development, Dissemination and Transfer of Knowledge of the Extremadura Research Groups", which is managed by the Council of Economy and Infrastructure of the Regional Government of Extremadura, Spain (Reference No. GR18109).

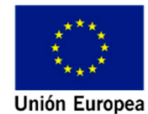

\section{JUNTA DE EXTREMADURA}

Fondo Europeo de Desarrollo Regional Una manera de hacer Europa

Conflicts of Interest: The authors declare no conflict of interest.

\section{References}

1. Hjalager, A.M.; Corigliano, M.A. Food for tourists-Determinants of an image. Int. J. Tour. Res. 2000, 4, 281-293. [CrossRef]

2. Bowdin, G.; Allen, J.; Harris, R.; McDonnell, I.; O’Toole, W. Events Management; Routledge: New York, NY, USA, 2012; ISBN 9781856178181.

3. Ritchie, J.B.; Crouch, G.I. The Competitive Destination: A Sustainable Tourism Perspective; Cabi: Oxon, UK, 2003; ISBN 0851996647.

4. López-Guzmán, T.; Uribe Lotero, C.P.; Pérez Gálvez, J.C.; Rios Rivera, I. Gastronomic festivals: Attitude, motivation and satisfaction of the tourist. Br. Food J. 2017, 2, 267-283. [CrossRef]

5. Baldy, J. Framing a Sustainable Local Food System-How Smaller Cities in Southern Germany Are Facing a New Policy Issue. Sustainability 2019, 6, 1712. [CrossRef]

6. Dimitrovski, D.; Crespi-Vallbona, M. Role of food neophilia in food market tourists' motivational construct: The case of La Boqueria in Barcelona, Spain. J. Travel Tour. Mark. 2017, 34, 475-487. [CrossRef]

7. Jiménez-Beltrán, F.; López-Guzmán, T.; González Santa Cruz, F. Analysis of the relationship between tourism and food culture. Sustainability 2016, 5, 418. [CrossRef]

8. Getz, D.; Andersson, T.; Vujicic, S.; Robinson, R.N. Food events in lifestyle and travel. Event Manag. 2015, 3, 407-419. [CrossRef]

9. Gálvez, J.; Granda, M.; López-Guzmán, T.; Coronel, J. Local gastronomy, culture and tourism sustainable cities: The behavior of the American tourist. Sustain. Cities Soc. 2017, 32, 604-612. [CrossRef]

10. Sparks, B.; Bowen, J.; Klag, S. Restaurant and the tourist market. Int. J. Contemp. Hosp. Manag. 2003, 1, 6-13. [CrossRef]

11. Oliveira, S. La gastronomía como atractivo turístico primario de un destino el turismo gastronómico en Mealhada-Portugal. Estud. Perspect. Tur. 2011, 20, 738-752.

12. Millán Vázquez de la Torre, G.; Hernández Rojas, R.; Navajas Romero, V. The study of gastronomic tourism in Cordoba and the association of the cuisine. An econometric analysis. Tour. Hosp. Manag. 2016, 2, 173-191. [CrossRef]

13. Sims, R. Food, place and authenticity: Local food and the sustainable tourism experience. J. Sustain. Tour. 2009, 3, 321-336. [CrossRef]

14. Privitera, D.; Nedelcu, A.; Nicula, V. Gastronomic and food tourism as an economic local resource: Case studies from Romania and Italy. Geoj. Tour. Geosites 2018, 1, 143-157.

15. Hillel, D.; Belhassen, Y.; Shani, A. What makes a gastronomic destination attractive? Evidence from the Israeli Negev. Tour. Manag. 2013, 36, 200-209. [CrossRef] 
16. Wood, E.H.; Long, P. Great Yorkshire Shows: The Role of Festivals in Regional Tourism Development, in Managing Regional Tourism: A Case Study of Yorkshire; Great Northern Books: Ilkley, UK, 2009.

17. Lee, I.; Arcodia, C. The role of regional food festivals for destination branding. Int. J. Tour. Res. 2011, 4, 355-367. [CrossRef]

18. Getz, D.; Robinson, R.N. Foodies and food events. Scand. J. Hosp. Tour. 2014, 3, 315-330. [CrossRef]

19. Kalkstein-Silkes, C.; Cai, L.A.; Lehto, X.Y. Conceptualizing Festival-Based Culinary. Food and Wine Festivals and Events around the World: Development, Management and Markets; Routledge: Osford, UK, 2008; ISBN.9780750683807.

20. Barrera, E.; Bringas, O. Las rutas alimentarias: Una arquitectura turística basada en la identidad de los alimentos. Sci. Gastron. 2008, 3, 2-11.

21. Fox, R. Reinventing the gastronomic identity of Croatian tourist destinations. Int. J. Hosp. Manag. 2007, 3, 546-559. [CrossRef]

22. Kim, Y.G.; Suh, B.W.; Eves, A. The relationships between food-related personality traits, satisfaction, and loyalty among visitors attending food events and festivals. Int. J. Hosp. Manag. 2010, 2, 216-226. [CrossRef]

23. Chi, C.; Qu, H. Examining the structural relationships of destination image and destination loyalty: An integrated approach. Tour. Manag. 2008, 4, 624-636. [CrossRef]

24. Quan, S.; Wang, N. Towards a structural model of the tourist experience: An illustration from food experiences in tourism. Tour. Manag. 2004, 3, 297-305. [CrossRef]

25. Folgado-Fernández, J.A.; Hernández-Mogollón, J.M.; Duarte, P. Destination image and loyalty development: The impact of tourists' food experiences at gastronomic events. Scand. J. Hosp. Tour. 2017, 1, 92-110. [CrossRef]

26. Wan, Y.K.P.; Chan, S.H.J. Factors that affect the levels of tourists' satisfaction and loyalty towards food festivals: A case study of Macau. Int. J. Tour. Res. 2013, 3, 226-240. [CrossRef]

27. Webb, J. Investigación de Marketing; Paraninfo: Madrid, Spain, 2003; ISBN 9788497322362.

28. Churchill, J. A paradigm for developing better measures of marketing constructs. J. Mark. Res. 1979, 1, 64-73. [CrossRef]

29. Etchtner, C.; Ritchie, B. The measurement of destination image: An empirical assessment. J. Travel Res. 1993, 4, 3-13. [CrossRef]

30. Boo, S.; Busser, J.; Baloglu, S. A model of customer-based brand equity and its application to multiple destinations. Tour. Manag. 2009, 2, 219-231. [CrossRef]

31. Kang, M.; Yang, S. Comparing effects of country reputation and the overall corporate reputations of a country on international consumers product attitudes and purchase intentions. Corp. Reput. Rev. 2010, 1, 52-56. [CrossRef]

32. Anholt, S. Competitive Identity: The New Brand Management for Nations, Cities and Regions; Palgrave Macmillan: New York, NY, USA, 2006; ISBN 9780230500280.

33. Getz, D. Event tourism: Definition, evolution, and research. Tour. Manag. 2008, 3, 403-428. [CrossRef]

34. Oh, H. Diner's perceptions of quality, value, \& satisfaction. Cornell Hotel Restaur. Adm. Q. 2000, 3, 58-66.

35. San Martín, H.; Rodríguez Del Bosque, I. Exploring the cognitive-affective nature of destination image and the role of psychological factors in its formation. Tour. Manag. 2008, 2, 263-277. [CrossRef]

36. Roldán, J.L.; Sánchez-Franco, M.J. Variance-based structural equation modeling: Guidelines for using partial least squares in information systems research. In Research Methodologies, Innovations and Philosophies in Software Systems Engineering and Information Systems; IGI Global: Hershey, PA, USA, 2012; pp. 193-221.

37. Kim, Y.G.; Eves, A.; Scarles, C. Building a model of local food consumption on trips and holidays: A grounded theory approach. Int. J. Hosp. Manag. 2009, 3, 423-431. [CrossRef]

38. Hair, J.F.; Sarstedt, M.; Pieper, T.M.; Ringle, C.M. The use of partial least squares structural equation modeling in strategic management research: A review of past practices and recommendations for future applications. Long Range Plan. 2012, 5-6, 320-340. [CrossRef]

39. Fornell, C.; Larcker, D.F. Evaluating structural equation models with unobservable variables and measurement error. J. Mark. Res. 1981, 1, 39-50. [CrossRef]

40. Teo, T.; Srivastava, S.; Jiang, L. Trust and electronic government success: An empirical study. J. Manag. Inf. Syst. 2008, 25, 99-132. [CrossRef]

41. Diamantopoulos, A.; Siguaw, J. Formative versus reflective indicators in organizational measure development: A comparison and empirical illustration. Br. J. Manag. 2006, 4, 263-282. [CrossRef] 
42. Andreev, P.; Heart, T.; Maoz, H.; Pliskin, N. Validating Formative Partial Least Squares (PLS) Models: Methodological Review and Empirical Illustration. Available online: https://aisel.aisnet.org/cgi/viewcontent. cgi? article $=1012 \&$ context $=$ icis2009 (accessed on 23 May 2019).

43. Hair, J.F., Jr.; Sarstedt, M.; Hopkins, L.; Kuppelwieser, V. Partial least 356 squares structural equation modeling (PLS-SEM) An emerging tool in business research. Eur. Bus. Rev. 2014, 2, 106-121. [CrossRef]

44. Chin, W. How to Write Up and Report PLS Analyses. In Handbook of Partial Least Squares: Concepts, Methods and Applications in Marketing and Related Fields; Vinzi, V.E., Chin, W.W., Wang, J.H.H., Eds.; Springer: Berlin, Germany, 2010; pp. 655-690.

45. Falk, R.; Miller, N. A Primer for Soft Modeling; The University of Akron: Akron, OH, USA, 1992.

(C) 2019 by the authors. Licensee MDPI, Basel, Switzerland. This article is an open access article distributed under the terms and conditions of the Creative Commons Attribution (CC BY) license (http://creativecommons.org/licenses/by/4.0/). 